\title{
LEAN ANTI-CORRUPTION TOOLKIT
}

\author{
Ahmed Stifi $^{1}$, Fritz Gehbauer ${ }^{2}$, and Sascha Gentes ${ }^{3}$
}

\begin{abstract}
When the Lean Construction revolution started about 25 years ago, it may have not have considered the issue of corruption.

The paper argues that corruption in construction forms a barrier in the implementation of Lean Construction. On the other hand, Lean Construction has the potential to combat corruption. Based on this contradiction, this paper shows how Lean Construction can be protected from corruption using something similar to a human immune system which includes Lean stem cells: transparency, accountability and integrity. Then paper shows how Lean Construction can play a vital role in combating corruption in construction via a Lean Anti-Corruption Toolkit.
\end{abstract}

Keywords: Lean Construction, Corruption, Integrity, Transparency, Accountability.

\section{INTRODUCTION}

Literature reviews and interviews with experts deliver many facts about corruption in construction. The first fact is that corruption is widely spread in the construction industry (Kenny, 2007; and TI, 2011). The second fact is that the construction industry contains most known forms of corruption such as bribery, embezzlement, fraud, extortion, collusion (including bid rigging, cover pricing, losers' fees and price fixing), facilitation payments, conflict of interest, nepotism, abuse of power and even money laundering (GIACC, 2008). The third fact is that efforts within the construction industry to combat corruption are less effective than in other industries and research conducted in this industry about corruption are not up to the level of importance and danger of this phenomenon.

The paper introduces integrity, transparency and accountability as fundamental core principles which act as body stem cells for Lean Construction. However, the intent of this paper is to invite the IGLC Committee into an open discussion about corruption and its position as waste in construction which must be eliminated by transplanting stem cells into Lean tools (in general into the body of Lean Construction).

\section{Solving the Problem of Corruption With A LEAN APPROACH}

One of the difficulties in combating corruption in different industries and especially in construction is seeing it as a complex problem and trying to ignore it intentionally or

1 Research Fellow, Institute for Technology and Management in Construction, Karlsruhe Institute of Technology (KIT), Karlsruhe, Germany, ahmed.stifi@kit.edu

2 Professor, Institute for Technology and Management in Construction, Karlsruhe Institute of Technology (KIT), Karlsruhe, Germany, fritz.gehbauer@kit.edu

3 Professor, Institute for Technology and Management in Construction, Karlsruhe Institute of Technology (KIT), Karlsruhe, Germany, sascha.gentes@kit.edu 
unintentionally. Instead of further complicating this topic, our research does not aim to make corruption a wicked problem, but rather to simplify its complexities and to reduce corruption systematically and continuously.

Whelton and Ballard (2002) see that the systematic step by step approaches to problem solving provides structure and direction to a decision problem. Our Lean based approach for solving corruption includes the four steps presented in Figure 1.

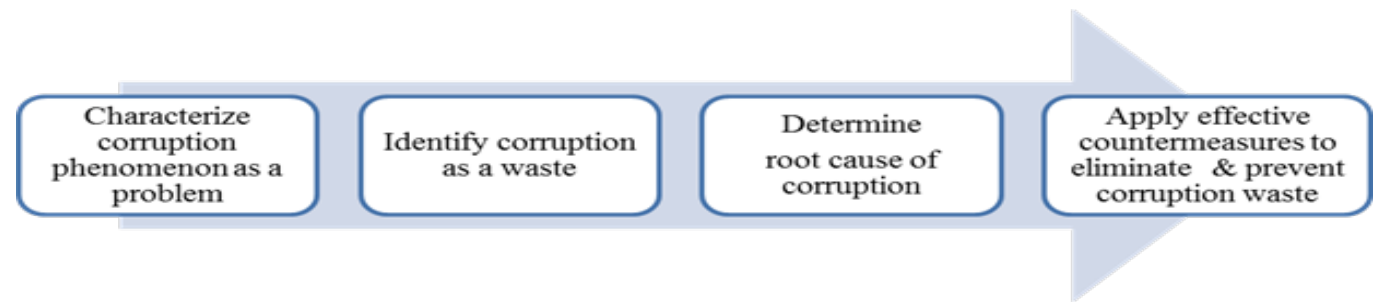

Figure 1: Lean Construction approach to solve corruption problem

\subsection{Corruption Waste}

The concept of waste is essential in Lean. When Lean Construction principles were developed, Koskela (2000) based his theory on seven waste types identified by Ohno. However, Koskela (2013) argues that the seven wastes introduced by Ohno were derived from the mass production industry and consequently do not cover all wastes found in the construction industry. Therefore, Koskela (2013) calls for searching and discovering new wastes within the construction industry. In our research, corruption is considered a kind of "waste". Moreover, the corruption phenomenon can be defined as a "core waste" according to Koskela's "chain of waste" where a core waste is "a phenomenon that is both a waste in itself and at the same time the cause of other wastes".

In order to eliminate the waste of corruption with the help of Lean, it is necessary to determine its root causes before effective countermeasures can be applied. From the Lean Construction's point of view there are three main reasons for corruption in construction; shown in the form of an Ishikawa diagram in Figure 2.

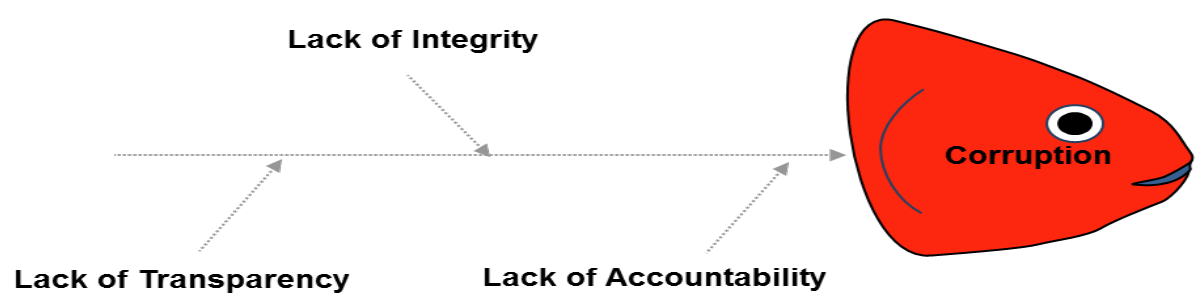

Figure 2: Causes of corruption in Lean Construction

In this context, Lean Construction can reduce the waste of corruption by increasing transparency and accountability and also by enhancing the integrity of persons and organizations.

\subsection{The Stem Cells of Lean}

What distinguishes the three reasons for corruption waste is a "lack of", i.e. corruption is caused by a deficiency in transparency, accountability and integrity. Therefore, transparency, accountability and integrity will be considered the "stem cells" of Lean Construction. Since using terms from other sciences is a good way to illustrate new 
concepts, as the medical term DNA has been used by Steven Spear and H. Kent Bowen in their article in the Harvard Business Review entitled "Decoding the DNA of the Toyota Production System", this research applies the concept of transplanting stem cells into the tools and concepts of Lean Construction to strengthen its immune system against corruption.

\section{Stem Cell Transparency:}

Undoubtedly, the term transparency is related to anti-corruption. "The greater the transparency, the more difficult it will be to conceal corruption" (TI, 2005). Several scholars also have shown that increasing transparency is a very important factor in reducing corruption (Sohail and Cavill, 2006; and Kolstad and Wiig, 2008). On the other hand, Lean considers transparency highly important. Womack (1996) says "transparency is the key principle in everything". Koskela (2000) considers the principle of transparency an important one. However, will transparency suffice to protect Lean from corruption and, consequently, to combat corruption?

Lambsdorff (2010) presents one answer when he discusses the problem of what he

calls "increased transparency". He stated that "there are, however, also some problems with transparency" and he introduced many cases in which transparency was used to facilitate corruption. Kolstad and Wiig (2008) see that transparency is necessary, but not a sufficient condition to reduce corruption.

Gehbauer expresses his concern that some parties involved in the construction process might use the mutually proffered transparency to serve their special interests. This would pose a conflict of interest. In the Last Planner System (LPS), conflicts of interest $(\mathrm{CoI})$ can be corrupt actions in disguise. Our research defines $\mathrm{CoI}$ in Lean as "the state or quality that can be attributed to a person, group or organization involved in a Lean project in which transparency provided by Lean to this person, group or organization is used without working on the same principle of transparency". In other words, it is the misuse of the transparency principle which poses a genuine threat to the successful implementation of Lean construction.

Based on the deconstruction of the transparency concept provided by Kolstad and Wiig (2008) and the many observations conducted during this research in various construction projects, the misuse of transparency can be defined as; (1) secrecy and withholding of information, (2) offering wrong information, (3) spin, (4) incomplete information, (5) inaccessible information, (6) unequal access to information, and (7) irrelevant information. This finding shows that transparency is necessary but not enough to reduce corruption. However, transparency is an important and essential principle in Lean Construction. The solution lies in supporting Lean with other principles that work to limit the misuse of transparency. These principles are accountability and integrity.

\section{Stem Cell Accountability:}

Accountability is the second element of the so-called "immune system" to protect Lean from corruption. Scholars often argue that the simultaneous lack of transparency and accountability is a reason for corruption. However, neither accountability nor corruption in the construction industry is often subject to studies (Nordin et.al, 2011). In fact, transparency is far more mentioned and applied in Lean than accountability. Also, Lean Construction mostly refers to responsibility than to accountability. Cavill and Sohail (2007) studied the difference between these two; they found blame to be the distinction between accountability and responsibility. Responsibility is having a job to do and taking the blame when things go wrong, while accountability is having the duty to explain and make amends without accepting blame. 
Koskela (2000) believes that "construction is the responsibility of a general contractor under contract to the client". He also found that there is a lack of leadership and responsibility for the total project. Ballard (2000) followed the same trend as Koskela when he explained that "the last planner system has previously been successively applied by firms with direct responsibility for production management; e.g. specialty contractors". The general approach in the LPS is to "allocate responsibility" by asking, "Who had responsibility for what?" However, arming Lean Construction with transparency and accountability will not protect it from corruption and eliminate corruption waste unless the third cause of corruption waste is considered.

\section{Stem Cell Integrity}

The third element of the "immune system" is integrity. Unfortunately, the principle of integrity is not yet part of the Lean principle. We believe that there are many reasons for ignoring integrity in Lean, e.g. the fact that the subject of corruption is generally ignored together with integrity-related topics like morality and truthfulness. Since integrity is not being widely discussed in the construction industry in general and in Lean Construction in particular; our researches carried out in-depth analyses about integrity to establish how Lean Construction could deal with it and add it to its agenda.

Many experts outside our field studied philosophical literature which discussed the phenomenon of "integrity". We found six views on integrity (aspects and model) discussed and introduced by Cox et.al (2005); Baxter et.al (2012) and Erhard et.al (2013): (1) integrity as self-integration, (2) the identity view of integrity, (3) integrity as standing for something, (4) integrity as moral purpose, (5) integrity as a virtue and (6) integrity as "honoring one's word". Erhard et.al (2013) connect integrity and production. They consider integrity as a production factor. They claim that the role of integrity in productivity and performance has been largely hidden or unnoticed, or even ignored by economists and others. People are looking for reasons for why things do not work and almost never consider out-of-integrity behaviour as a cause. Instead, they supply explanations, rationalizations, justifications, and excuses. Erhard says: "this masquerade hides the role played by the out-of-integrity behaviour's impact on performance".

This paper argues that integrity plays an important role that has been overlooked in the construction industry, even in Lean Construction which has always fervently sought to improve productivity. Lean's main goal is to improve performances; as a matter of fact, low performances in the construction industry were the spark igniting the Lean Construction revolution (Koskela, 2000). The challenge lies in a suitable model for integrity which suits the core of Lean. "Simplicity" is the most important criterion for an integrity model or concept that is also suitable for Lean. Simplicity is considered an important principle in Lean and a basis for considering matters and discussing them.

Erhard et.al (2013) introduced a model for integrity and called it "honoring one's word"; i.e. you either keep your word (do what you said you would do and by the time you said you would do it); or, as soon as you know that you will not, you say that you will not and clean up any mess caused for those who were counting on your word. Our research recommends that Lean Construction adopts Erhard's model of integrity "honoring one's word" because it is the most comprehensive model which includes all the other (five) aspects of integrity, especially those of morality, ethics and legality. This would results in reliable promises; especially when considering that "one's word" equals "promise" in the Last Planner System. 


\section{INTEGRITY STEM CELL TRANSPLANTATION INTO LPS}

Within the scope of this research, a case study was designed, using action research to transplant the concept of integrity as "honoring one's word" into the LPS. We propose to adopt this concept in Lean Construction. Our strategy depends on the LPS as a platform to promote transparency, accountability, and integrity. The application of these concepts should consequently reduce corruption since their lack is the main reason for corruption as defined in this paper. The LPS already promotes transparency and accountability, however, the missing principle is integrity.

The case study revealed that the participants did not respect their respective commitments due to different conflicts of interest. For example, we recorded a corrupt case in which location and assembly flow of one subcontractor was negatively impacted by an area manager who would not give approval to commence work unless he was paid a certain sum, otherwise the manager would not let the subcontractor start work as promised. Another example was about obtaining permission to enter the site; its refusal preventing the proper flow of machines and labour. Here, the possibility of bribing the person giving entrance permission was recorded. Moreover, and in general, it was observed that most of the people in the project easily made promises without the intention of honouring them.

We used the LPS as a training platform to enhance integrity and to inform the participants about the importance of integrity "honoring one's word" as a factor to the successful execution of the project, workshops and simulations of many cases were carried out within LPS sessions. Figure 3 (right side) shows the average PPC values of both phases of the case study, in Phase I (before transplantation of integrity) PPC= $71.58 \%$, and in Phase II (after transplantation of integrity) PPC $=82.32 \%$, i.e. in our case study the PPC valued increased by 11 percentage points. The figure shows also that all subcontractors have improved their PPC values in different ratios (left side).

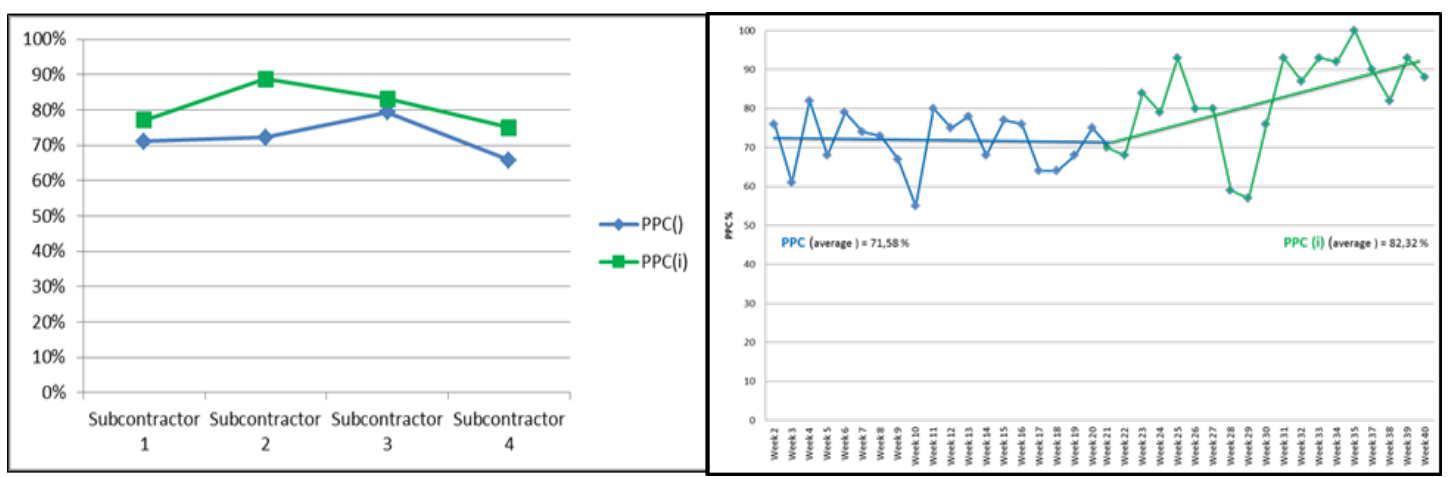

Figure 3: PPC values of Phase I and Phase II

The improvement of the PPC value in the case study cannot be attributed to the introduction of the integrity model alone. Here, the increase in the PPC value is also a result of the continuous LPS implementation because the work team, by time, got used to the concepts of the LPS. Therefore, other improvement factors also applied. Several past studies about the LPS proved this point. Supposedly, if we had not introduced the integrity concept there could still have been some improvement in the PPC. Therefore, the improvement cannot be attributed entirely to the integrity concept alone. 
However, a last planner person with integrity working to honour his promise (honouring one's word) will adapt a positive "can do" attitude and carefully consider all constraints to ensure that he will keep his promises .In this case, the last planner (and everybody in this production chain working with integrity) tries to avoid any conflict of interest and simultaneously becomes an internal observer and monitor looking for all obstacles in the way of honouring the promise. Of course, corruption and corrupt people are main obstacles, like the above mentioned "corrupt area manager".

The case study shows how integrity can play a vital role in changing a corruptive "culture" through striving for reliable promises. However, eliminating corruption requires Lean to transplant the integrity principle into other Lean tools and to benchmark other tools and ideas as best practices to combat corruption. This lead us to develop a Lean Anti-Corruption Toolkit consisting of the elements listed in the next paragraph.

\section{LEAN ANTI-CORRUPTION TOOLKIT}

The remaining step of our problem-solving approach is to apply effective countermeasures to reduce corruption waste. Here, we carried out a benchmarking process, looking for the best practices in the field of anti-corruption. The most important principles, concepts and tools used by other organizations to combat corruption in addition to our new integrity model in Lean Construction were assembled in a toolkit called "Lean Anti-Corruption Toolkit". It consists of the following:

Integrity Management System (IMS): IMS guides a Lean organization on how to apply the integrity concept (including standards of moral and ethics) to every aspect of its business. This helps create the right procedure to prevent and eliminate corruption waste. (FIDIC, 2015)

ISO 37001: This can be one of the Lean organization tools for reducing corruption waste, especially bribery. It is preferable for a Lean organization to connect it to its quality management system ISO 9001(ISO 37001, 2016)

Due Diligence (DD): The Lean organization can use Due Diligence as an effective tool to talk with its parties about corruption waste directly, and to determine the issues from which corruption waste can result during running the construction process. (GIACC, 2008; and ISO 37001, 2016)

Anti-Corruption Contract Terms: Lean contracts, IPD, IFoA, and Alliance Contracts or any form of innovated contracts introduced by Lean should contain anti-corruption terms which can be considered anti-corruption commitments included in the contract. The design of anti-corruption clauses may range from simple requirements to more sophisticated regulations. (GIACC, 2008; and FIDIC, 2015)

Integrity Pact (IP): The IP is a tool introduced by Transparency International, it can be used as it is and could be further developed in Lean as a criterion for suppliers partners in the production process (Sohail and Cavill, 2006).

Project Code of Conduct (P-CoC): The Lean organization should develop a code of conduct applicable at project level. P-CoC could be a formal declaration of the project values and its working rules.

Integrity into LPS: It is important to modify the current LPS by integrating the integrity principle into it and training the last planners in "honoring one's word" which will result in spreading the integrity culture among business partners; making them the base for spreading it in their organisation. 
Reward and Discipline Policy: Rewarding and discipline behaviour with or without integrity can be linked to the incentive system of the organization. At the same time, the repeated plan failure should be discussed with last planners from an integrity point of view and failure reasons should be analysed without neglecting corruption causes.

Declaration of Conflict of Interest: Lean construction should use a "conflict of interest declaration" as a tool for persons in leading positions to declare whether they have relatives in the project or with the suppliers, to avoid that these relations lead to a kind of conflict of interest affecting the aims and values of the project.

Green-Box (GB): We suggest a so-called "Green-box" to be set in the hall of a project management's office, so that anybody can report any corrupt incidents that may occur, may have known about or may have been asked to participate in. This tool will help reporting without referring to the person directly (whistleblowing protection policy).

Training: Training remains the essential and effective tool to achieve the goal of reducing corruption waste. It is necessary to update the current training platforms within Lean construction to take corruption waste into consideration. In this context, LPS remains the best training platform to achieve this purpose.

Capacity Building (CB): Adopting the anti-corruption movement requires continuous capacity building in this field, so that the Lean organization develops the know-how for eliminating corruption. Capacity building in Lean Construction also involves the important principle "train the trainer". Members of Lean organizations who received advanced training and knowledge on how to reduce corruption should be required to train other staff members in projects (on-site) on how to spread the culture of integrity and eliminate corruption waste in their projects.

\section{CONCLUSION}

This paper introduces an important type of waste in construction by defining corruption as a core waste creating other wastes. It also introduces a new important principle in Lean: "integrity" which complements the already existing principles of transparency and accountability. The paper proposes to use the LPS as a practical platform for combating corruption in construction projects, in combination with the introduced Lean AntiCorruption Toolkit.

It is highly recommended to integrate the components of the toolkit into Lean and to combine them for maximum effect.

Since this research is considered one of the first studying the corruption phenomenon in depth within Lean Construction, it can be generally assumed that there are still many opportunities for researches on this topic within Lean Construction.

\section{REFERENCES}

Ballard, G. (2000). "The Last Planner System of Production Control." Thesis submitted to the Faculty of Engineering of The University of Birmingham

Baxter, J.; Dempsey, J.; Megone, C. and Lee, J. (2012) "Real Integrity: Practical solutions for organisations seeking to promote and encourage integrity" University of Leeds Chartered Accountants' Trustees Limited, London, UK

Cavill, S. and Sohail, M. (2007). "Accountability Arrangements to Combact Corruption Literature Review.” Water, Engineering and Development Center (WEDC) 
Cox, D.; La Caze, M. and Levin, M. (2005). "Integrity" The Stanford Encyclopedia of Philosophy, Fall-2013, Stanford Encyclopedia of Philosophy

Erhard, W.; Jensen, C. and Zaffron, S. (2013). "Integrity: A Positive Model that incorporates the Normative Phenomena of Morality, Ethics, and Legality."

Fauchier, D. and Alves, T. C. L. (2013). "Last Planner System is the Gateway to Lean Behaviors.” IGLC 21., Fortaleza, Brazil.

FIDIC (2015). "Guidelines For Integrity Management in The Consulting Industry - Part II: FIMS Procedure" Federation of Consulting Engineering (FIDIC), Geneva, Switzerland

GIACC (2008). “Anti-Corruption Training Manual: Infrastructure, Construction and Engineering Sectors.” Global Infrastructure Anti-Corruption Centre, London, UK

Kenny, C. (2007). "Construction, Corruption, and Developing Countries" World Bank Policy Research Working Paper 4271, World Bank (WB), USA

Kolstad, I. and Wiig, A. (2008). "Is Transparency the Key to Reducing Corruption in Resource-Rich Countries?” Elsevier, World Development Vol. 37, No. 3.

Koskela, L. (2000). "An Exploration Towards a Production Theory and its Application to Construction" PhD thesis, Espo, Helsinki University of Technology, Finland

Koskela, L.; Bølviken, T. and Rooke, J. (2013). "Which are the Wastes of Construction?" IGLC 21., Fortaleza, Brazil.

Lambsdorff, J. G. (2010). "The Organization of Anticorruption - Getting Incentives Right!” Diskussionsbeitrag Nr. V-57-08, University of Passau, Germany

Nordin, R. M.; Takim, R. and Nawawi A. H. (2011). "Critical Factors Contributing to Corruption in Construction Industry.” IEEE Symposium on Business, Engineering and Industrial Applications (ISBEA), Langkawi, Malaysia

Sohail, M. and Cavill, S. (2006). "Corruption in construction projects." Proceedings of the CIB W107 Construction in Developing Countries Symposium, Santiago, Chile

Transparency International (2005) "Corruption in Construction - Recommendation Report” Transparency International (TI), Berlin, Germany

Transparency International (2011) "Bribe Payers Index 2011 - Report" Transparency International (TI), Berlin, Germany

Whelton, M. and Ballard, G. (2002). "Wicked Problems in Project Definition." IGLC 10., Brazil

Womack, J. and Jones, D. (1996) "Lean Thinking: Banish Waste and Create Wealth in your Corporation” Free Press, Simon \& Schuster Inc., ISBN 0-7432-4927-5, USA 